\title{
HUBUNGAN KONDISI FISIK RUMAH DENGAN KEJADIAN TB PARU DI WILAYAH KERJA PUSKESMAS KALIBAGOR KABUPATEN BANYUMAS TAHUN 2016
}

\author{
Titi Kurniasih, ${ }^{1)}$ Budi Triyantoro, ${ }^{2)}$ Arif Widyanto, ${ }^{3)}$ \\ Jurusan Kesehatan Lingkungan, Politeknik Kesehatan Kemenkes Semarang, \\ Jl.Raya Baturaden KM 12 Purwokerto, Indonesia
}

\begin{abstract}
Abstrak
Jumlah kasus TB paru di wilayah kerja Puskesmas Kalibagor tahun 2013 sebanyak 38 kasus dan pada tahun 2014 menurun menjadi 31 kasus. Kasus TB Paru baru masih terjadi, tidak terlepas kondisi fisik rumah yang belum seluruhnya memenuhi persyaratan kesehatan. Tujuan dari penelitian ini yaitu untuk mengetahui hubungan kondisi fisik rumah dengan kejadian tuberkulosis paru di wilayah kerja Puskesmas Kalibagor Kabupaten Banyumas Tahun 2016. Rancangan penelitian ini menggunakan case control dengan pendekatan retrospektif. Populasi kasus yaitu semua pasien TB Paru baru di Puskesmas Kalibagor Kabupaten Banyumas tahun 2015 sebanyak 36 orang. Sampel kasus diambil secara total sampling dari pasien TB paru baru yaitu 36 orang dan sampel kontrolnya diambil dari warga masyarakat yang tidak menderita TB paru sebanyak 36 orang. Hasil penelitian ini menyimpulkan kondisi lantai yang memenuhi syarat sebagian besar tidak menderita TB Paru $(56,9 \%)$ dengan $p$ value sebesar 0,017 dengan OR sebesar 4,840. Kondisi ventilasi yang memenuhi syarat sebagian besar tidak menderita TB Paru (63,9\%) dengan $p$ value sebesar 0,018 dengan OR sebesar 3,130. Kepadatan hunian rumah yang memenuhi syarat sebagian besar tidak menderita TB Paru (59,2\%) dengan nilai p value sebesar 0,023 dengan OR sebesar 3,314. Penelitian ini menyimpulkan bahwa ada hubungan antara kondisi fisik rumah (kondisi lantai, ventilasi dan kondisi kepadatan rumah) dengan kejadian TB paru di wilayah kerja Puskesmas Kalibagor Kabupaten Banyumas Tahun 2016. Sebaiknya penderita TB Paru tidak tidur dengan anggota keluarga lain. Ventilasi normal minimal $10 \%$ dari luas lantai ruangan, lantai rumah dibuat kedap air dan kuat. Penelitian ini diharapkan dapat dipublikasikan agar dapat menambah referensi ilmiah yang dapat dijadikan rujukan bagi peneliti selanjutnya yang meneliti permasalahan yang sama.
\end{abstract}

Kata Kunci : : TB Paru, Rumah

\begin{abstract}
The number of cases of pulmonary TB in Puskesmas Kalibagor in 2013 there were 38 cases and in 2014 decreased to 31 cases. Pulmonary TB new cases still occur, despite no physical condition that has not entirely meet the health requirements. The purpose of this study is to determine the relationship of physical condition and the incidence of pulmonary tuberculosis in Puskesmas Kalibagor Banyumas 2016. The design of this study using a retrospective case control approach. Population case that all new pulmonary TB patients at health centers Kalibagor Banyumas in 2015 as many as 36 people. Samples taken in the case of total sampling of new pulmonary TB patients is 36 and the control samples were taken from citizens who do not suffer from pulmonary TB as many as 36 people. The results of this study concluded that the condition of the floor qualified majority do not suffer from pulmonary tuberculosis (56.9\%) with a $p$ value of 0.017 with an OR of 4.840. Ventilation conditions qualified majority do not suffer from pulmonary tuberculosis (63.9\%) with a $p$ value of 0.018 with an OR of 3.130. Density residential house qualified majority do not suffer from pulmonary tuberculosis (59.2\%) with a $p$ value of 0.023 with an OR of 3.314. The study concluded that there is a relationship between physical condition (condition of the floor, ventilation and density conditions of the house) with the incidence of pulmonary tuberculosis in Puskesmas Kalibagor Banyumas Year 2016. You should not sleep with pulmonary tuberculosis with other family members. Normal ventilation of at least 10\% of the floor area of the room, floor home made watertight and strong. This study is expected to be published in order to increase scientific references that can be used as a reference for further research that examines the same problem.
\end{abstract}

Keywords : : Pulmonary TB, House

\footnotetext{
1) E-mail: titikurniasih585@gmail.com

2) E-mail: mutshabira@yahoo.co.id

3) E-mail: arifwidyanto74@yahoo.com
} 


\section{PENDAHULUAN}

Menurut Gordon. J dalam Annies (2006), bahwa kejadian sakit pada seseorang atau sekelompok masyarakat dipengaruhi oleh beberapa faktor, yaitu faktor Agent (penyebab penyakit), Host (pejamu), populasi berisiko) dan Environmental (lingkungan). Penyakit Tuberkulosis paru (TB Paru) merupakan salah satu penyakit berbasis lingkungan yang masih menjadi masalah utama kesehatan masyarakat di dunia termasuk Indonesia. Tuberkulosis paru adalah penyakit infeksi menular yang disebabkan oleh bakteri Mycobacterium tuberculosis, TB Paru menjadi penyebab kematian ketiga setelah penyakit kardiovaskuler dan penyakit saluran pernapasan pada semua kelompok umur serta penyebab kematian nomor satu dari golongan penyakit infeksi pernapasan (Depkes RI, 2008).

Indonesia sampai dengan tahun 2014 menempati urutan kedua dari 5 negara terbesar di dunia sebagai penyumbang penderita TB terbanyak setelah negara India, China, Nigeria dan Pakistan. Pada tahun 2015, beban global penyakit TB (prevalensi dan mortalitas) akan relatif berkurang sebesar $50 \%$ dibandingkan tahun 1990 , dan setidaknya $70 \%$ orang yang terinfeksi TB dapat dideteksi dengan strategi DOTS dan 85\% diantaranya dinyatakan sembuh (Kemenkes RI, 2015).

Penelitian yang dilakukan oleh Deny (2014) menyimpulkan bahwa kepadatan hunian, ventilasi alami di ruangan yang dominan digunakan, ventilasi alami di kamar tidur, pencahayaan alami di ruangan yang dominan digunakan, dan pencahayaan alami di kamar tidur berhubungan dengan kejadian TB Paru. Jenis lantai, kelembaban di ruangan yang dominan digunakan dan kelembaban di kamar tidur tidak berhubungan dengan kejadian TB Paru. Sepertiga dari populasi dunia sudah tertular dengan tuberkulosis paru dimana sebagian besar penderita tuberkulosis paru adalah usia produktif (15-55 tahun) (Kementrian Kesehatan RI, 2012)

Berdasarkan WHO

Global

Report 2014, angka Insidens TB tahun
2014 adalah 183/100.000 penduduk, sedangkan angka prevalensi TB adalah 272/100.000 penduduk dan angka mortalitas TB adalah 25/100.000 penduduk. Pada tahun 2014 (Kemenkes RI, 2015).

Jumlah kasus TB Paru di wilayah kerja Puskesmas Kalibagor tahun 2013 sebanyak 38 kasus dan pada tahun 2014 menurun menjadi 31 kasus. Meskipun sudah terjadi penurunan kasus TB Paru, jumlahnya masih cenderung tinggi. Data rumah tinggal di wilayah kerja Puskesmas Kalibagor dari sebanyak 12.246 rumah, terdapat sebanyak 1.802 rumah semi permanen, 3.682 rumah dengan dinding rumah dari kayu dan 960 rumah dengan dinding rumah dari bahan bambu (Kecamatan Kalibagor, 2014). Kasus TB Paru baru masih terjadi, tidak terlepas kondisi fisik rumah yang belum seluruhnya memenuhi persyaratan kesehatan.

Berdasarkan permasalahan di atas, peneliti tertarik untuk melakukan penelitian dengan mengambil judul "Hubungan Kondisi Fisik Rumah dengan Kejadian Tuberkulosis Paru di Wilayah Kerja Puskesmas Kalibagor Kabupaten Banyumas Tahun 2016".

Penelitian ini bertujuan untuk Mengetahui hubungan kondisi fisik rumah dengan kejadian tuberkulosis paru di wilayah kerja Puskesmas Kalibagor, Kabupaten Banyumas Tahun 2016.

\section{METODE PENELITIAN}

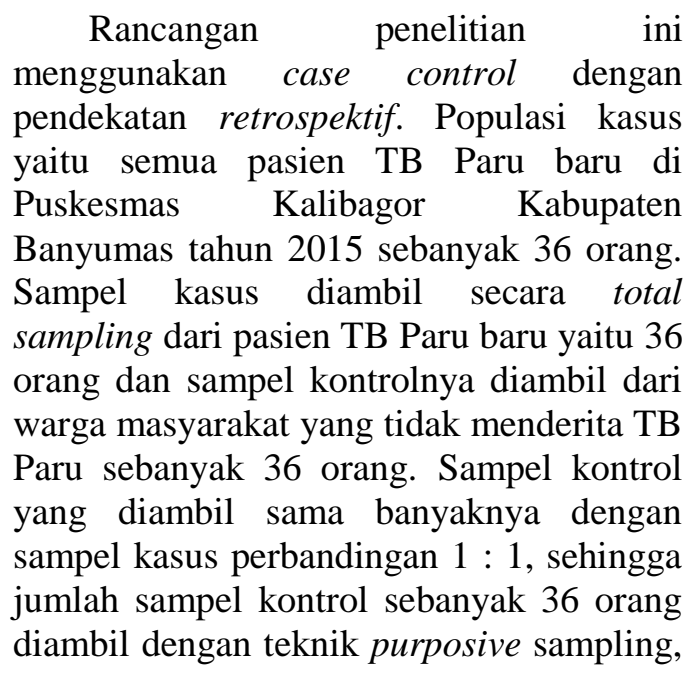


yaitu mengambil keluarga yang bertempat tinggal di sebelah atau bertetangga dengan sampel kasus dan tidak ada keluarga penderita TB paru.

\section{HASIL PENELITIAN DAN PEMBAHASAN}

\section{A. Hasil Analisis Univariat}

Analisis univariat dilakukan untuk mendeskripsikan setiap variabel yang diteliti yang meliputi kondisi fisik rumah (lantai, ventilasi, kepadatan hunian rumah) dan kejadian TB Paru yang hasilnya disajikan pada tabel 4.5 berikut ini.

Tabel 1.

Kondisi Fisik Rumah Responden di Kecamatan Kalibagor tahun 2016
3. Kepadatan Hunian Rumah

Responden yang diteliti sebanyak 72 rumah, kondisi kepadatan hunian rumah responden yang tidak memenuhi syarat sebanyak 23 rumah $(31,9 \%)$ dan yang memenuhi syarat sebanyak 49 rumah $(68,1 \%)$.

4. Kejadian TB Paru

Responden yang diteliti sebanyak 72 orang dengan penderita TB Paru sebanyak 36 orang $(50,0 \%)$ dan yang tidak menderita TB Paru sebanyak 36 rumah $(50,0 \%)$.

\begin{tabular}{|c|c|c|c|c|}
\hline No & Variabel & Kategori & Jumlah & $\%$ \\
\hline \multirow[t]{3}{*}{1.} & \multirow[t]{3}{*}{ Lantai Rumah } & Tidak memenuhi syarat & 14 & 19,4 \\
\hline & & Memenuhi syarat & 58 & 80,6 \\
\hline & & Jumlah & 72 & 100,0 \\
\hline \multirow[t]{3}{*}{2.} & Ventilasi & Tidak memenuhi syarat & 36 & 50,0 \\
\hline & \multirow{2}{*}{ Rumah } & Memenuhi syarat & 36 & 50,0 \\
\hline & & Jumlah & 72 & 100,0 \\
\hline \multirow[t]{3}{*}{3.} & \multirow{3}{*}{$\begin{array}{l}\text { Kepadatan } \\
\text { Rumah }\end{array}$} & Tidak memenuhi syarat & 23 & 31,9 \\
\hline & & Memenuhi syarat & 49 & 68,1 \\
\hline & & Jumlah & 72 & 100,0 \\
\hline \multirow[t]{3}{*}{4.} & \multirow[t]{3}{*}{ Kejadian TB Paru } & Ya & 36 & 50,0 \\
\hline & & Tidak & 36 & 50,0 \\
\hline & & Jumlah & 72 & 100,0 \\
\hline
\end{tabular}

Hasil analisis univariat dapat diuraikan sebagai berikut.

1. Lantai Rumah

Responden yang diteliti sebanyak 72 rumah, kondisi lantai rumah responden yang tidak memenuhi syarat sebanyak 14 rumah $(19,4 \%)$ dan yang memenuhi syarat sebanyak 58 rumah $(80,6 \%)$.

2. Ventilasi Rumah

Responden yang diteliti sebanyak 72 rumah, kondisi ventilasi rumah responden yang tidak memenuhi syarat sebanyak 36 rumah $(50,0 \%)$ dan yang memenuhi syarat sebanyak 36 rumah $(50,0 \%)$.

\section{B. Hasil Analisis Bivariat}

Analisis bivariat dilakukan untuk mengetahui hubungan kondisi fisik rumah dengan kejadian TB Paru di wilayah kerja Puskesmas Kalibagor Kabupaten Banyumas Tahun 2016. Hasil analisis bivariat menggunakan uji Chi Square hasilnya disajikan pada tabel 2 berikut ini. 
Tabel 2.

Hasil Analisis Hubungan Kondisi Fisik

Rumah Dengan Kejadian TB Paru di

Kecamatan Kalibagor tahun 2016

\begin{tabular}{|c|c|c|c|c|c|c|c|c|c|}
\hline \multirow{3}{*}{ No } & \multirow{3}{*}{ Variabel } & \multirow{3}{*}{ Kategori } & \multicolumn{4}{|c|}{ Kejadian TB Paru } & \multirow{3}{*}{$\begin{array}{l}p \\
\text { value }\end{array}$} & \multirow{3}{*}{ OR } & \multirow{3}{*}{ CI95\% } \\
\hline & & & \multicolumn{2}{|c|}{$\mathrm{Ya}$} & \multicolumn{2}{|c|}{ Tidak } & & & \\
\hline & & & $\mathrm{n}$ & $\%$ & $\mathrm{n}$ & $\%$ & & & \\
\hline \multirow[t]{3}{*}{1.} & \multirow[t]{3}{*}{ Lantai Rumah } & $\begin{array}{l}\text { Tidak } \\
\text { memenuhi } \\
\text { syarat }\end{array}$ & 11 & 78,6 & 3 & 21,4 & \multirow[t]{3}{*}{0,017} & \multirow[t]{3}{*}{4,840} & $\begin{array}{l}1,220- \\
19,206\end{array}$ \\
\hline & & $\begin{array}{l}\text { Memenuhi } \\
\text { syarat }\end{array}$ & 25 & 43,1 & 33 & 56,9 & & & \\
\hline & & Jumlah & 36 & 50,0 & 36 & 50,0 & & & \\
\hline \multirow[t]{3}{*}{2.} & \multirow[t]{3}{*}{$\begin{array}{l}\text { Ventilasi } \\
\text { Rumah }\end{array}$} & $\begin{array}{l}\text { Tidak } \\
\text { memenuhi } \\
\text { syarat }\end{array}$ & 23 & 63,9 & 13 & 36,1 & \multirow[t]{3}{*}{0,018} & 3,130 & $\begin{array}{l}1,196- \\
8,190\end{array}$ \\
\hline & & $\begin{array}{l}\text { Memenuhi } \\
\text { syarat }\end{array}$ & 13 & 36,1 & 23 & 63,9 & & & \\
\hline & & Jumlah & 36 & 50,0 & 36 & 50,0 & & & \\
\hline \multirow[t]{3}{*}{3.} & \multirow[t]{3}{*}{$\begin{array}{l}\text { Kepadatan } \\
\text { Hunian Rumah }\end{array}$} & $\begin{array}{l}\text { Tidak } \\
\text { memenuhi } \\
\text { syarat }\end{array}$ & 16 & 69,6 & 7 & 30,4 & \multirow[t]{3}{*}{0,023} & \multirow[t]{3}{*}{3,314} & $\begin{array}{l}1,154- \\
9,520\end{array}$ \\
\hline & & $\begin{array}{l}\text { Memenuhi } \\
\text { syarat }\end{array}$ & 20 & 40,8 & 29 & 59,2 & & & \\
\hline & & Jumlah & 36 & 50,0 & 36 & 50,0 & & & \\
\hline
\end{tabular}

Hasil analisis bivariat tersebut pada tabel 2 dapat dijelaskan sebagai berikut.

1. Hubungan kondisi lantai rumah dengan kejadian tuberkulosis paru di wilayah kerja Puskesmas Kalibagor Kabupaten Banyumas Tahun 2016

Berdasarkan pada tabel 4.6 diketahui bahwa orang yang tinggal di rumah dengan kondisi lantai rumah tidak memenuhi syarat sebagian besar menderita TB Paru $(78,6 \%)$ dan yang tinggal di rumah dengan kondisi lantai memenuhi syarat sebagian besar tidak menderita TB Paru (56,9\%). Hasil uji Chi Square diperoleh nilai $p$ value sebesar 0,017 yang lebih kecil dari $\alpha=$ 0,05 artinya ada hubungan antara kondisi lantai rumah dengan kejadian tuberkulosis paru di wilayah kerja Puskesmas Kalibagor Kabupaten Banyumas Tahun 2016. Nilai OR sebesar 4,840 artinya orang yang tinggal di rumah dengan kondisi lantai tidak memenuhi syarat berisiko menderita TB Paru 4,840 kali lebih besar dibandingkan yang tinggal di rumah dengan kondisi lantai rumah memenuhi syarat.

2. Hubungan kondisi ventilasi rumah dengan kejadian tuberkulosis paru di wilayah kerja Puskesmas Kalibagor Kabupaten Banyumas Tahun 2016

Berdasarkan pada tabel 4.6 diketahui bahwa orang yang tinggal di rumah dengan kondisi ventilasi rumah tidak memenuhi syarat sebagian besar menderita TB Paru $(63,9 \%)$ dan yang tinggal di rumah dengan kondisi ventilasi memenuhi syarat sebagian besar tidak menderita TB Paru (63,9\%). Hasil uji Chi Square diperoleh nilai $p$ value sebesar 0,018 yang lebih kecil dari $\alpha=0,05$ artinya ada hubungan antara kondisi ventilasi rumah dengan kejadian tuberkulosis 
paru di wilayah kerja Puskesmas Kalibagor Kabupaten Banyumas Tahun 2016. Nilai OR sebesar 3,130 artinya orang yang tinggal di rumah dengan kondisi ventilasi rumah tidak memenuhi syarat berisiko menderita TB Paru 3,130 kali lebih besar dibandingkan yang tinggal di rumah dengan kondisi ventilasi rumah memenuhi syarat.

3. Hubungan kondisi kepadatan hunian rumah dengan kejadian tuberkulosis paru di wilayah kerja Puskesmas Kalibagor Kabupaten Banyumas Tahun 2016

Berdasarkan pada tabel 2 diketahui bahwa orang yang tinggal di rumah dengan kondisi kepadatan hunian rumah tidak memenuhi syarat sebagian besar menderita TB Paru $(69,6 \%)$ dan yang tinggal di rumah dengan kondisi kepadatan hunian rumah memenuhi syarat sebagian besar tidak menderita TB Paru $(59,2 \%)$. Hasil uji Chi Square diperoleh nilai $p$ value sebesar 0,023 yang lebih kecil dari $\alpha=0,05$ artinya ada hubungan antara kondisi kepadatan hunian rumah dengan kejadian tuberkulosis paru di wilayah kerja Puskesmas Kalibagor Kabupaten Banyumas Tahun 2016. Nilai OR sebesar 3,314 artinya orang yang tinggal di rumah dengan kondisi kepadatan hunian rumah tidak memenuhi syarat berisiko menderita TB Paru 3,314 kali lebih besar dibandingkan yang tinggal di rumah dengan kondisi kepadatan hunian rumah memenuhi syarat.

Responden yang diteliti sebanyak 72 rumah, kondisi lantai rumah responden yang tidak memenuhi syarat sebanyak 14 rumah $(19,4 \%)$ dan yang memenuhi syarat sebanyak 58 rumah $(80,6 \%)$.

Responden yang diteliti sebanyak 72 rumah, kondisi ventilasi rumah responden yang tidak memenuhi syarat sebanyak 36 rumah $(50,0 \%)$ dan yang memenuhi syarat sebanyak 36 rumah $(50,0 \%)$.
Responden yang diteliti sebanyak 72 rumah, kondisi kepadatan hunian rumah responden yang tidak memenuhi syarat sebanyak 23 rumah $(31,9 \%)$ dan yang memenuhi syarat sebanyak 49 rumah $(68,1 \%)$.

Responden yang diteliti sebanyak 72 orang dengan penderita TB Paru sebanyak 36 orang $(50,0 \%)$ dan yang tidak menderita TB Paru sebanyak 36 rumah $(50,0 \%)$.

Berdasarkan hasil penelitian pada tabel 4.6 diketahui bahwa orang yang tinggal di rumah dengan kondisi lantai rumah tidak memenuhi syarat sebagian besar menderita TB Paru $(78,6 \%)$ dan yang tinggal di rumah dengan kondisi lantai memenuhi syarat sebagian besar tidak menderita TB Paru $(56,9 \%)$.

Hasil penelitian tersebut menunjukkan bahwa kondisi lantai rumah yang tidak memenuhi syarat cenderung berisiko terkena TB Paru. Hal ini juga didukung dengan hasil uji statistik yang menunjukkan ada hubungan antara kondisi lantai rumah dengan kejadian tuberkulosis paru di wilayah kerja Puskesmas Kalibagor Kabupaten Banyumas Tahun 2016 ( $p$ value $=0,017$ ). Nilai OR sebesar 4,840 artinya orang yang tinggal di rumah dengan kondisi lantai tidak memenuhi syarat berisiko menderita TB Paru 4,840 kali lebih besar dibandingkan yang tinggal di rumah dengan kondisi lantai rumah memenuhi syarat.

Berdasarkan pada tabel 2 diketahui bahwa orang yang tinggal di rumah dengan kondisi ventilasi rumah tidak memenuhi syarat sebagian besar menderita TB Paru $(63,9 \%)$ dan yang tinggal di rumah dengan kondisi ventilasi memenuhi syarat sebagian besar tidak menderita TB Paru $(63,9 \%)$.

Hasil penelitian tersebut menunjukkan bahwa kondisi ventilasi rumah yang tidak memenuhi syarat cenderung berisiko terkena TB Paru. Hal ini juga didukung dengan hasil uji statistik yang menunjukkan ada 
hubungan antara kondisi ventilasi rumah dengan kejadian tuberkulosis paru di wilayah kerja Puskesmas Kalibagor Kabupaten Banyumas Tahun 2016 ( $p$ value $=0,018)$. Nilai OR sebesar 3,130 artinya orang yang tinggal di rumah dengan kondisi ventilasi rumah tidak memenuhi syarat berisiko menderita TB Paru 3,130 kali lebih besar dibandingkan yang tinggal di rumah dengan kondisi ventilasi rumah memenuhi syarat.

Berdasarkan pada tabel 2 diketahui bahwa orang yang tinggal di rumah dengan kondisi kepadatan hunian rumah tidak memenuhi syarat sebagian besar menderita TB Paru $(69,6 \%)$ dan yang tinggal di rumah dengan kondisi kepadatan hunian rumah memenuhi syarat sebagian besar tidak menderita TB Paru $(59,2 \%)$.

$\begin{array}{ccc}\text { Hasil } & \text { penelitian } & \text { tersebut } \\ \text { menunjukkan } & \text { bahwa } & \text { kondisi }\end{array}$ kepadatan hunian rumah yang tidak memenuhi syarat cenderung berisiko terkena TB Paru. Hal ini juga didukung dengan hasil uji statistik yang menunjukkan ada hubungan antara kondisi kepadatan hunian rumah dengan kejadian tuberkulosis paru di wilayah kerja Puskesmas Kalibagor Kabupaten Banyumas Tahun 2016 ( $p$ value $=0,023$ ). Nilai OR sebesar 3,314 artinya orang yang tinggal di rumah dengan kondisi kepadatan hunian rumah tidak memenuhi syarat berisiko menderita TB Paru 3,314 kali lebih besar dibandingkan yang tinggal di rumah dengan kondisi kepadatan hunian rumah memenuhi syarat.

\section{SIMPULAN DAN SARAN}

\section{A. Simpulan}

Kesimpulan penelitian berdasarkan hasil penelitian dan pembahasan sebagai berikut :

1. Kondisi lantai rumah responden sebagian besar memenuhi syarat sebanyak 58 rumah $(80,6 \%)$, kondisi ventilasi rumah responden yang tidak memenuhi syarat sebanyak 36 rumah $(50,0 \%)$ dan yang memenuhi syarat sebanyak 36 rumah $(50,0 \%)$, kondisi kepadatan hunian rumah responden yang tidak memenuhi syarat sebanyak 23 rumah $(31,9 \%)$ dan yang memenuhi syarat sebanyak 49 rumah $(68,1 \%)$.

2. Responden penderita TB paru sebanyak 36 orang $(50,0 \%)$ dan yang tidak menderita TB paru sebanyak 36 orang $(50,0 \%)$.

3. Ada hubungan antara kondisi fisik rumah (kondisi lantai, ventilasi dan kondisi kepadatan rumah) dengan kejadian TB paru di wilayah kerja Puskesmas Kalibagor Kabupaten Banyumas Tahun 2016.

\section{B. Saran}

Saran-saran yang dapat diberikan terkait dengan kesimpulan penelitian sebagai berikut :

1. Bagi Puskesmas

Perlu adanya kerjasama dengan pihak Lintas Sektoral khususnya Desa dalam rangka perbaikan rumah yang memenuhi syarat kesehatan dan meningkatkan penyuluhan bidang kesehatan khususnya upaya pencegahan penyakit TB Paru.

2. Bagi Masyarakat

Sebaiknya penderita TB Paru tidak tidur dengan anggota keluarga lain. Ventilasi normal minimal $10 \%$ dari luas lantai ruangan, lantai rumah dibuat kedap air dan kuat.

3. Bagi Pendidikan

Penelitian ini diharapkan dapat dipublikasikan agar dapat menambah referensi ilmiah yang dapat dijadikan rujukan bagi peneliti selanjutnya yang meneliti permasalahan yang sama. 


\section{Daftar Pustaka}

Achmadi, U.F. 2005. Manajemen Penyakit Berbasis Wilayah. Kompas : Jakarta.

Almatsier S. 2009. Prinsip Dasar Ilmu Gizi. Jakarta, Gramedia.

Andi, Tenri Aty S. 2013. Hubungan Antara Pengetahuan Dan Sikap Penderita Tuberkulosis Paru Dengan Perilaku Pencegahan Penularan Basil Mycobacterium Tuberkulosa di Ruang Rawat Inap RSUD Pangkep. http://library.stikesnh.ac.id/files/disk $1 / 9 / \mathrm{e}-$

library\%20stikes\%20nani\%20hasanu ddin--anditenria-420-1-361492981.pdf

Annies, 2006. Manajemen Berbasis Lingkungan; Solusi Mencegah dan Menanggulangi Penyakit Menular. Elex Media Komputindo, Jakarta,

Arikunto, S. 2006. Prosedur Penelitian Suatu Pendekatan Praktik. Rineka Cipta. Jakarta.

Bahar A. 2009. Buku Ajar Ilmu Penyakit Dalam. Jakarta : Balai Penerbit FKUI

Budiarto.Eko 2004. Metode Penelitian. EGC. Jakarta.

Budiman, N.E. 2010, Analisis Faktor yang Berhubungan dengan Kepatuhan Minum Obat Pasien TB Paru pada Fase Intensif di Rumah Sakit Umum Cibabat Cimahi. http://stikesayani.ac.id/publikasi/ejournal/filesx/2010/201008/201008007.pdf

Dahlan, Sopiyudin M, 2008. Langkah-langkah Membuat Proposal Penelitian Bidang. Kedokteran dan Kesehatan. Sagung Seto.Jakarta.

Depkes, RI. 2006. Pedoman Nasional Penanggulangan Tuberkulosis. Depkes RI. Jakarta.
--------------, 2008. Pedoman Nasional Penanggulangan Tuberkulosis. Depkes RI. Jakarta.

Deny A. 2014. Hubungan Kondisi Fisik Lingkungan Rumah dengan Kejadian Tuberkulosis Paru di Wilayah Kerja Puskesmas Perumnas $i$ dan II Kecamatan Pontianak Barat. http://jurnal.untan.ac.id/index.php/jfk /article/download/7838/7931

Fatimah, Siti. 2008. Faktor Kesehatan Lingkungan Rumah Yang Berhubungan Dengan Kejadian TB Paru Di Kabupaten Cilacap (Kecamatan : Sidareja, Cipari, Kedungreja, Patimuan, Gandrungmangu, Bantarsari) Tahun 2008.

http://eprints.undip.ac.id/24695/1/siti _fatimah.pdf

Kementrian Kesehatan RI, 2012. Laporan Situasi Terkini Perkembangan Tuberkulosis di Indonesia JanuariDesember 2012. www.depkes.go.id

Kemenkes RI, 2015. Pelaksanaan Hari TB Sedunia 2015 Di Provinsi Bali Selasa, $24 \quad$ Maret 2015. http://www.diskes.baliprov.go.id/id/pe laksanaan-hari-tb-sedunia-2015-diprovinsi-bali-selasa--24-maret-20152

McMurray DN and Cegielski JP,. 2009. The relationship between malnutrition and tuberculosis, evidence from studies in humans and experimental animals. International Journal of Tuberculosis and Lung Disease 2004;8(3):286-98.

Melisah Pitri Siregar. 2012. Hubungan Karakteristik Rumah Dengan Kejadian Penyakit Tuberkulosis Paru Di Puskesmas Simpang Kiri Kota Subulussalam Tahun 2012. http://jurnal.usu.ac.id/index.php/lkk/a rticle/download/1219/619

Murti, B. 2010. Prinsip dan Metode Riset Epidemiologi, Gajah Mada University Press, Yogyakarta. 
Ngastiyah, 1997. Perawatan Anak Sakit. EGC. Jakarta.

Notoatmodjo, S. 2005. Metodologi Penelitian Kesehatan. Rineka Cipta. Jakarta.

2007. Kesehatan Masyarakat Ilmu dan Seni. Rineka Cipta. Jakarta.

Nursalam, 2012. Konsep dan Penerapan Metodologi Penelitian Ilmu Keperawatan. Salemba Medika. Jakarta.

Permatasari, A., 2005. Pemberantasan Penyakit TB Paru dan Strategi DOTS. USU e- Repository.

Rahim Noer W. 2014. Angka Kejadian Penemuan Tuberkulosis Paru pada Pasien Bronkiektasis di Balai Besar Kesehatan Paru Masyarakat Surakarta Tahun 2012 Sampai 2013. http://eprints.ums.ac.id/28325/

Rukmini dan Chatarina U.W. 2011. FaktorFaktor Yang Berpengaruh Terhadap Kejadian TB Paru Dewasa Di Indonesia (Analisis Data Riset Kesehatan Dasar Tahun 2010). http://ejournal.litbang.depkes.go.id/in dex.php/hsr/article/download/1369/2 193

Rusnoto; Pasihan, R. 2006. Faktor-Faktor yang Berhubungan dengan Kejadian Tuberkulosis Paru pada Usia Dewasa (Studi Kasus di Balai Pencegahan dan Pengobatan Penyakit Paru Pati), Semarang: Universitas Diponogoro

Salim, Emil. 2009. Lingkungan Hidup dan Pembangunan, Mutiara, Jakarta.
Djasio, Sanropi. 1989. Komponen Sanitasi Rumah Sakit untuk Institusi Pendidikan Tenaga Sanitasi. EGC. Jakarta.

Siti Nur, 2008. Hubungan Tingkat Pengetahuan dan Sikap dengan Perilaku Pencegahan Penularan TBC pada Mahasiswa di Asrama Monokwari Sleman Yogyakarta, http://journal.uad.ac.id/index.php/Kes Mas/article/view/1109

Soedarto, 1990. Zoonosis Kedokteran. Universitas Airlangga, Surabaya.

Tobing, L.T. 2009. Pengaruh Perilaku Penderita TB Paru dan Kondisi Rumah Terhadap Pencegahan Potensi Penularan TB Paru pada Keluarga di Kabupaten Tapanuli Utara.

http://repository.usu.ac.id/bitstream/1 23456789/6656/1/09E01348.pdf.

Triman, Daryatno, 2002, Faktor-Faktor yang Mempengaruhi Kekambuhan Tuberkulosis Paru Strategi DOTS di Puskesmas dan BP4 di Surakarta dan Wilayah Sekitarnya. Tesis, Universitas Diponegoro Semarang

Wahyu Nur Firdiansyah. 2012. Pengaruh Faktor Sanitasi Rumah dan Sosial Ekonomi Terhadap Kejadian Penyakit TB Paru BTA Positif Di Kecamatan Genteng Kota Surabaya. http://ejournal.unesa.ac.id/article/122 31/40/article.pdf

WHO, 2010. Guidance for National Tuberculosis Programme on the Management of Tuberculosis in children. WHO. Genewa. 